\title{
Isolation and culture of stem cells derived from dental pulp of permanent teeth: a successful method
}

\author{
Isolamento e cultura de células-tronco derivadas da polpa de dentes \\ permanentes: um método bem sucedido
}

Cíntia de Vasconcellos Machado*

Carolina Montagn Carvalho*

Taís Menezes Cerqueira Campos ${ }^{* * *}$

Sara Timóteo Passos ${ }^{* * * *}$

Paloma Dias da Silva Telles ${ }^{* * * *}$

\begin{abstract}
Objective: To establish cultures of cells from the pulp of permanent teeth by the explant method assessing parameters usually presented by stem cells, such as the expression of certain markers and the differentiation ability into osteogenic, adipogenic, and chondrogenic lineages. This study also aimed to assess the expression of ALDH1 (aldehyde dehydrogenase 1) enzyme activity on the isolated cells. Materials and method: The pulp tissue, obtained from wisdom teeth, was placed in a 6-well plate containing proper culture medium, and stored at $37{ }^{\circ} \mathrm{C}$ and $5 \% \mathrm{CO}_{2}$ for cell proliferation and plastic adherence. Cells were tested for the expression of surface markers and for ALDH1 enzyme activity, by flow cytometry. In addition, cells were assessed for multi-differentiation potential. Results: The isolated cells showed high expression of CD44 (98.8\%), CD73 (100\%), and CD90 (97.2\%), and moderate expression of STRO-1 (18.4\%) and ALDH1 (16.2\%), by flow cytometry. Similarly, the cells showed differentiation ability into all three lineages of cells tested. Conclusion: Our results suggest that the explant method - or cell proliferation method - is suitable for the isolation and culture of stem cells from dental pulp of permanent teeth. The isolated cells may be considered stem cells, based on the current criteria for their characterization, such as plastic adherence, expression of certain markers, and the absence of others, as well as multi-differentiation
\end{abstract}

potential, which showed to be promising for the application in tissue regeneration.

Keywords: Stem cells. Dental pulp. Isolation. ALDH1.

\section{Introduction}

Over the last years, dentistry has been exploring the potential application of stem cells from different origins in the regeneration of oral tissues that were lost or damaged by disease or trauma ${ }^{1}$. Mesenchymal stem cells (MSCs) constitute one of the most promising types of stem cells, because they are available in tissues, show multi-differentiation potential, lack ethical issues, and do not form teratomas $^{2}$. Mesenchymal stem cells may supply cell demands of the tissue they belong to, acquiring local phenotypic characteristics. When necessary, and after receiving the appropriate molecular signals from the microenvironment, MSCs create progenitor cells committed to a particular cell lineage ${ }^{3}$.

However, currently, there is no specific marker or a combination of markers able to identify MSCs. Hence, the isolation of MSCs also depends on biologi-

PhD, Assistant Professor, Metropolitan University of Education and Culture (Unime), Department of Orthodontics and Pediatric Dentistry, School of Dentistry, Salvador, Bahia, Brazil

$\mathrm{PhD}$, Research Fellow, Federal University of Bahia (UFBA), Center of Biophotonics, School of Dentistry, Salvador, Bahia, Brazil

MS, Graduate Student, Federal University of Bahia (UFBA), Immunology Service, University Hospital Professor Edgar Santos, Salvador, Bahia, Brazil $\mathrm{PhD}$, Research Fellow, Federal University of Bahia (UFBA), Immunology Service, University Hospital Professor Edgar Santos, Salvador, Bahia, Brazil PhD, Associate Professor, Department of Social and Pediatric Dentistry, School of Dentistry, Federal University of Bahia (UFBA), Salvador, Bahia, Brazil 
cal characteristics, such as colony-forming ability, fibroblast-like morphology (these cells are also known as colony-forming unit fibroblasts - CFU-Fs), plastic adherence, proliferative ability, and self-renewal and multi-differentiation potential ${ }^{4}$. Despite the lack of specific markers, MSCs often express STRO-1, CD44, CD73, CD90, and CD105, and are negative for CD31, CD34, CD45, CD80, CD86, and HLA-DR ${ }^{5,6}$. The aldehyde dehydrogenase 1 (ALDH1) is an intracellular enzyme that has been used to isolate and purify different populations of stem cells, as hematopoietic, neural, and cancer stem cells, but not $\mathrm{MSCs}^{7,8}$.

Stem cells were first isolated from dental pulp by Gronthos and co-workers, in the year $2000^{9}$. These cells, called dental pulp stem cells (DPSCs), usually express mesenchymal stem cell markers. Only one study in literature was able to identify ALDH1 enzyme activity on DPSCs, through the immunocytochemistry analysis ${ }^{10}$.

Dental pulp stem cells are not only able to differentiate into odontoblasts, but they can form an organized dentin-pulp-like complex lined with odontoblast-like cells, when seeded onto a scaffold and transplanted into immunocompromised mice ${ }^{1}$. Similarly, DPSCs may also differentiate into the osteogenic, chondrogenic, and adipogenic cell lineages, considering this multi-differentiation potential is the minimum requirement for DPSCs to be considered stem cells ${ }^{6,11,12}$. Thus, the stem cells isolated from dental pulp present a great utility potential in regenerative dentistry ${ }^{1}$.

However, there is a large variation regarding isolating methods and culture conditions of stem cells, as well as different origins of tissues and species, which would explain the large variation in the expression of surface markers among MSCs, and perhaps the lack of a specific marker to identity and purify this special group of cells ${ }^{13}$. The two most widely applied isolation methods for harvesting stem cells may be the enzymatic digestion of tissue and the explant method. The explant method is based upon the plastic adherence of MSCs and subsequent outgrowth of cells from tissue fragments, whereas the enzymatic digestion involves the use of collagenase 1 and dispase to digest pulp tissue to acquire single-cell suspensions $s^{2,5,12,13}$.

Therefore, this study aimed to establish cell cultures of pulp cells by the explant method, assessing parameters usually presented by mesenchymal stem cells, such as the expression of certain markers and the multi-differentiation potential. We also aimed to verify the expression of ALDH1 enzyme activity on the isolated cells.

\section{Materials and method}

This study was approved by the Ethics Committee of the Federal University of Bahia (Brazil), registered under n. 06/11, in accordance with national and international guidelines and regulations of the Declaration of Helsinki. All the patients or patient's guardians signed an informed consent form.

\section{Isolation and culture of dental pulp cells}

After the extraction of wisdom teeth from patients aged 16 to 18 years, grooves were made with a diamond bur, at high speed and constant irrigation, to access the pulp chamber, being careful not to reach the soft tissue. Inside the hood, teeth were cracked open and the pulp was removed. Next, the connective tissue was cut into pieces of $1 \mathrm{~mm}^{3}$; transferred to a 6-well plate with Dulbecco's modified Eagle's medium - DMEM (Gibco, Invitrogen, Grand Island, NY, USA); supplemented with $10 \%$ fetal bovine serum (Laborclin, Pinhais, Brazil), 100 $\mathrm{U} / \mathrm{mL}$ of penicillin, $100 \mu \mathrm{g} / \mathrm{mL}$ of streptomycin, and $10 \mu \mathrm{g} / \mathrm{mL}$ of amphotericin B (Gibco); and stored at $37 \square \mathrm{C}$ and $5 \% \mathrm{CO}_{2}$ for cell proliferation, through the explant method and plastic adherence. The culture medium was changed every 3 or 4 days. When the culture reached about $90 \%$ confluence, cells were collected with $0.25 \%$ trypsin-EDTA (Gibco), and transferred to culture flasks until a new passage was required.

\section{Flow cytometry}

A total of $5 \times 10^{5}$ cells per tube was incubated for $15 \mathrm{~min}$, at $4{ }^{\circ} \mathrm{C}$ with $5 \mu \mathrm{L}$ of CD44, CD45, CD73, CD90 (BD Biosciences, Mountain View, CA, USA), STRO-1 (Invitrogen) or IgG (BD Pharmingen ${ }^{\mathrm{TM}}$ ), conjugated with FITC or APC (BD Pharmingen ${ }^{\mathrm{TM}}$ ) fluorochromes. The Aldefluor kit (Stem Cell Technologies, Durham, NC, USA) was used for detection of ALDH1 enzyme activity. A total of $1 \times 10^{6}$ cells was briefly suspended with either activated Aldefluor substrate (BODIPY-aminoacetaldehyde - BAAA) or negative control (diethylaminobenzaldehyde - DEAB), for $45 \mathrm{~min}$ at $37^{\circ} \mathrm{C}$. Flow cytometry analysis was performed on cells in the fifth passage. Data were obtained with the FACSDiVA Cell Sorter (BD Biosciences) flow cytometer, wherein 200,000 events were collected and analyzed.

\section{Cell differentiation in vitro}

In order to assess the ability of isolated cells to differentiate into osteogenic, adipogenic, and chondrogenic lineages, fifth-passage cells were seeded on a 12 -well plate, at a density of $5 \times 10^{3}$ cells $/ \mathrm{cm}^{2}$. When cultures reached $60 \%$ confluence, the growth medium was replaced by a specific induction medium (STEMPRO ${ }^{\mathrm{TM}}$ Osteogenesis, Adipogenesis or Chondrogenesis Differentiation Kit, Invitrogen), which was replaced every 3 or 4 days. The cells were maintained in each of these differentiation mediums, from 2 to 4 weeks. For each experiment, 
we used a negative control consisting of the same cells maintained in conventional culture medium.

After the period of differentiation, cultures were washed with deionized water and fixed in $4 \%$ paraformaldehyde, for $1 \mathrm{~h}$. The cells subjected to osteogenic differentiation were stained with Alizarin Red (Sigma-Aldrich, St Louis, USA), for adipogenic differentiation - Oil Red (Sigma-Aldrich), and for chondrogenic differentiation - Alcian Blue (Sigma Sigma-Aldrich).

\section{Results}

\section{Isolation and culture of dental pulp cells}

The establishment of cell cultures by the explant method was considered successful. After 48 $\mathrm{h}$ of pulp culture, cells started to migrate from the tissue and proliferate on the plate. About two weeks after the beginning of culture, the cells reached about $90 \%$ confluence on the plate and showed a fibroblastoid shape.

\section{Immunophenotyping}

The results from flow cytometry analysis confirmed the MSCs characteristics of the isolated cells. More than $90 \%$ of the cells in the culture were positive for CD44, CD73, and CD90, whereas moderate labeling was observed for STRO-1 and ALDH1. The cells showed negative expression for CD45 and for the controls. The percentage values found in the flow cytometry tests are listed in Table 1.

Table 1 - Representation of percentage values obtained in flow cytometry analysis of the dental pulp isolated cells

\begin{tabular}{l|c|}
\hline \multicolumn{1}{|c|}{ Cell Markers } & Percentage Values \\
\hline CD44 & $98.8 \%$ \\
CD73 & $100 \%$ \\
CD90 & $97,2 \%$ \\
STRO-1 & $18.4 \%$ \\
CD45 & $0,13 \%$ \\
ALDH1 & $16,2 \%$ \\
\hline
\end{tabular}

\section{Cell differentiation in vitro}

The isolated cells were able to differentiate into the three cell lineages tested. The multi-lineage differentiation potential of the cells was confirmed by using standard immunocytochemical staining. After 4 weeks of induction, Oil Red $\mathrm{O}$ staining presented lipid droplets in the cultures subjected to adipogenic differentiation. The osteogenic differentiation was observed by the calcium deposits stained with Alizarin Red, and the chondrogenic differentiation could be seen by the Alcian Blue staining of the glycosaminoglycans. Both osteogenic and chondrogenic differentiated cells were visualized after 2 weeks of induction. Figure 1 shows the differentiated cells.
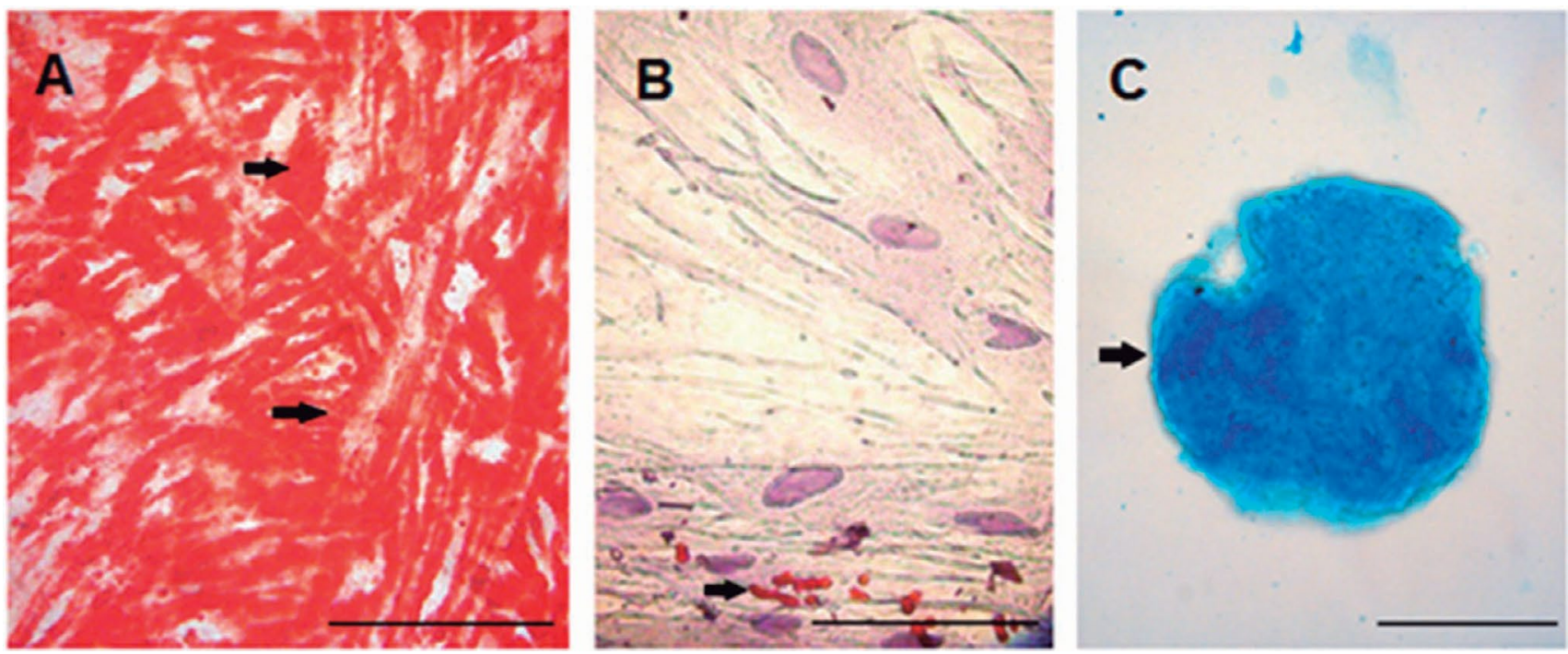

Figure 1 - Multiple lineage differentiation properties of the isolated dental pulp cells. (a) Osteogenic differentiation visualized by calcium deposits stained with Alizarin Red. (b) Adipogenic differentiation visualized by Oil Red staining showing lipid vacuoles. (c) Chondrogenic differentiation visualized by Alcian Blue staing of glycosaminoglycans. Scale bars: $50 \mu \mathrm{m}$.

\section{Discussion}

Method of isolation, cell proliferation, and expression of stem cell markers are important aspects for the successful use of dental pulp stem cells. Different isolation methods are described in the literature and there is no current consensus established regarding the preferred or the most appropriate and practical isolation method ${ }^{12}$. Previous studies that have used either the explant or the outgrowth method for DPSCs isolation (by which stem cells grow directly from the tissue into the flask, with proper culture medium and without the use of enzymes) showed similar results to those described in 
the present study, regarding the establishment of cultures, morphological characteristics of cells, expression pattern of surface antigens, and multi-differentiation potential ${ }^{14-16}$. When both the explant method and the enzymatic digestion were compared, no significant differences were found between cell cultures from same donors, suggesting that both methods may be applied to obtain DPSCs ${ }^{12}$.

In terms of cellular morphology, adherent elongated fibroblast-like cells could be visualized in this study, after 24 or 48 hours, which agrees with previous observations ${ }^{9,11,12}$. A 90\% confluence of DPSCs is usually reached after 10 to 14 days of culture, with the explant method ${ }^{12,17}$. Our results showed similar $90 \%$ cell confluence after two weeks of tissue culture, demonstrating the effectiveness of the isolation method employed.

Phenotypically, the DPSCs are characterized by expressing a set of cell surface markers and by the absence of others. However, there is no specific marker for characterizing these cells ${ }^{18}$. Thus, different cell markers have been described and tested in order to define this population of cells. In our study, the isolated pulp cells showed positive expression for the mesenchymal stem cell markers CD44, CD73, CD90, and STRO-1, and showed no expression for the hematopoietic marker CD45, agreeing with previous reports ${ }^{6,11,12,17,19}$.

STRO-1 shows a variable expression level by flow cytometry in human pulp cells ( $1.2 \%$ to $9.56 \%)$, despite being considered a genuine marker of mesenchymal stem cells ${ }^{9,18,20}$. In bone marrow, STRO$1^{-}$cells were unable to form colonies, meaning they do not contain CFU-Fs ${ }^{21}$. On the other hand, MSCs isolated from the umbilical cord blood, based on the expression of this marker, showed an increased ability to engraft to the affected areas when transplanted into immunosuppressed mice ${ }^{22}$. In addition, STRO- $1^{+}$cells are able to differentiate into adipogenic, chondrogenic, and osteogenic lineages ${ }^{23}$. In this study, the expression of STRO-1 was $18.4 \%$, which can be considered a high value when compared to other reports ${ }^{9,18,20}$. However, the expression of this marker may be lost during successive passages of the cells ${ }^{20}$. Therefore, the results of this study suggest that STRO-1 could be used in association with other MSCs markers, such as CD44, CD73, and CD90, to characterize DPSCs.

The activity of the cytosolic enzyme ALDH1 has been used to identify and purify different stem cell populations, such as cancer, neural, and hematopoietic stem cells ${ }^{8,9}$. According to Douville et al. ${ }^{8}$ (2009), different populations of stem cells show high ALDH1 activity, and flow cytometry aided by Aldefluor $^{\mathrm{TM}}$ could be considered a "universal marker" for the isolation of stem cells from several origins. This is the first study that assessed the expression of ALDH on DPSCs through flow cytometry. Although there are no references in the literature regarding the activity of ALDH1 on DPSCs, the expression le- vel found in this study for the isolated pulp cells may be considered high (16.2\%), since the percentage of ALDH1 positive cells in distinct stem cell cultures is usually low, ranging from 0.96 to $3.5 \%{ }^{24}$. In addition, $\mathrm{ALDH}^{+}$cells would be more primitive, with a more undifferentiated profile ${ }^{7}$.

According to the International Society for Cellular Therapy, another criterion to define mesenchymal stem cells is the in vitro multi-lineage differentiation potential ${ }^{6}$. The isolated dental pulp cells in this study presented potential for differentiation into osteogenic, adipogenic, and chondrogenic cell lineages, proving that the explant method is viable and accessible for the isolation of dental pulp stem cells.

\section{Conclusions}

The establishment of cell cultures by the explant method was considered successful, since a suitable population of DPSCs was obtained. These data suggest that the isolated pulp cells may be considered stem cells, since they met some basic criteria, such as plastic adherence, expression of certain surface markers, and the absence of others, in addition to the multi-differentiation potential. It is also suggested that ALDH1 enzyme activity could be used to isolate and characterize DPSCs. Further studies assessing a few stem cell parameters of $\mathrm{ALDH}^{+}$pulp cells, such as stem cell expression and embryonic markers, are required to enable the use of these cells in studies in vivo, for the regeneration of damaged and/or lost tissues.

\section{Acknowledgements}

The authors would like to thank the Immunology Service from the University Hospital Professor Edgar Santos, Federal University of Bahia (UFBA), Brazil. This work was funded by FAPESB (Foundation for Research Support of the State of Bahia).

\section{Resumo}

Objetivo: estabelecer culturas de células da polpa de dentes permanentes por meio do método explant, avaliando nessas células parâmetros usualmente apresentados por células-tronco, como a expressão de determinados marcadores e a capacidade de diferenciação nas linhagens osteogênica, condrogênica e adipogênica. $O$ estudo também teve como objetivo avaliar a expressão da atividade da enzima ALDH1 (aldeído dehydrogenase1) nas células isoladas. Método: o tecido pulpar obtido a partir de terceiros molares foi acondicionado em placa de seis poços contendo meio de cultura apropriado e armazenado a $37^{\circ} \mathrm{C}$ e $5 \%$ de $\mathrm{CO}_{2}$ para a proliferação celular e aderência ao plástico. As células foram testadas quanto à expressão de marcadores de superfície e à atividade da enzima ALDH1, por meio da citometria de fluxo. Além disso, as células foram avaliadas quan 
to à capacidade de multidiferenciação. Resultados: as células isoladas mostraram alta expressão para CD44 $(98,8 \%), C D 73(100 \%)$ e CD90 $(97,2 \%)$ e uma expressão moderada para STRO-1 (18,4\%) e ALDH1 (16,2\%), por meio da citometria de fluxo. Da mesma forma, as células foram capazes de se diferenciar nas três linhagens celulares testadas. Conclusão: os resultados sugerem que o método explant, ou de proliferação celular, é adequado para o isolamento de células-tronco da polpa de dentes permanentes. As células isoladas podem ser consideradas células-tronco, de acordo com os critérios correntes para caracterização de tais células, como aderência ao plástico, expressão de certos marcadores e ausência de outros, assim como capacidade de multidiferenciação, apresentando um potencial promissor para a aplicação na regeneração tecidual.

Palavras-chave: Células-tronco. Polpa dentária. Isolamento. ALDH1.

\section{References}

1. Casagrande L, Cordeiro MM, Nör AS, Nör JE. Dental pulp stem cells in regenerative dentistry. Odontology 2011; 99(1):1-7.

2. Da Silva Meirelles L, Caplan AI, Nardi NB. In search of in vivo identity of mesenchymal stem cells. Stem cells 2008; 26(9):2287-99.

3. Da Silva Meirelles L, Chagastelles PC, Nardi NB. Mesenchymal stem cells reside in virtually all post-natal organs and tissues. J Cell Sci 2006; 119(11):2204-13.

4. Yan M, Yu Y, Zhang G, Tang C, Yu J. A journey from dental pulp stem cells to a bio-tooth. Stem Cell Rev and Rep 2011; 7(1):161-71.

5. Musina RA, Bekchanova ES, Sukhikh GT. Comparison of mesenchymal stem cells obtained from different human tissues. Bull Exp Biol Med 2005; 139(4):504-9.

6. Dominici M, Le Blanc K, Mueller I, Slaper-Cortenbach I, Marini FC, Krause DS, et al. Minimal criteria for defining multipotent mesenchymal stromal cells. The International Society for Cellular Therapy position statement. Cytotherapy $2006 ; 8(4): 315-7$.

7. Moreb JS. Aldehyde dehydrogenase as a marker for stem cells. Curr Stem Cell Res Ther 2008; 3(4):237-46.

8. Douville J, Beaulieu R, Balicki, D. ALDH1 as a functional marker of cancer stem and progenitor cells. Stem Cells Dev $2009 ; 18(1): 17-25$

9. Gronthos S, Mankani M, Brahim J, Robey PG, Shi S. Postnatal dental pulp stem cells (DPSCs) in vitro and in vivo. Proc Natl Acad Sci USA 2000; 97(25):13625-30.

10. Telles PDS, Nör JE. Expressão de ALDH e CD44 em células-tronco da polpa dentária. Braz Oral Res 2007; 21(Suppl.1):223-83.

11. Bakopoulou A, Leyhausen G, Volk J, Tsiftsoglou A, Garefis $\mathrm{P}$, Koidis $\mathrm{P}$, et al. Comparative analysis of in vitro osteo/ odontogenic differentiation potential of human dental pulp stem cells (DPSCs) and stem cells from the apical papilla (SCAP). Arch Oral Biol 2011; 56(7):709-21.

12. Hilkens P, Gervois P, Fanton Y, Vanormelingen J, Martens W, Struys T, et al. Effect of isolation methodology on stem cell properties and multilineage differentiation potential of human dental pulp stem cells. Cell Tissue Res 2013; 353(1):65-78.

13. Javason EH, Beggs KJ, Flake AW. Mesenchymal stem cells: paradoxes of passaging. Exp Hematol 2004; 32(5):414-25.
14. Struys T, Moreels M, Martens W, Donders R, Wolfs E, Lambrichts I. Ultrastructural and immunocytochemical analysis of multilineage differentiated human dental pulp and umbilical cord derived mesenchymal stem cells. Cells Tissues Organs 2010; 193(6):366-78.

15. Huang GT, Sonoyama W, Chen J, Park SH. In vitro characterization of human dental pulp cells: various isolation methods and culturing environments. Cell Tissue Res 2006; 324(2):225-36

16. Jesus AA, Soares MBP, Soares AP, Nogueira RC, Guimarães ET, Araújo TM, et al. Collection and culture of stem cells derived from dental pulp of deciduous teeth: technique and clinical case report. Dental Press J Orthod 2011; 16(6):111-8.

17. Bernardi L, Luisi SB, Fernandes R, Dalberto TP, Valentim $\mathrm{L}$, Bogo Chies JA, et al. The isolation of stem cells from human deciduous teeth pulp is related to the physiological process of resorption. J Endod 2011; 37(7):973-9.

18. Karamzadeh R, Eslaminejad MB, Aflatoonian R. Isolation, characterization and comparative differentiation of human dental pulp stem cells derived from permanent teeth by using two different methods. J Vis Exp 2012; 24(69): 4372.

19. Yamaza T, Kentaro A, Chen C, Liu Y, Shi Y, Gronthos S, et al. Immunomodulatory properties of stem cells from human exfoliated deciduous teeth. Stem Cell Res Ther 2010; 1(1):5.

20. Simmons PJ, Torok-Storb B. Identification of stromal cell precursors in human bone marrow by a novel monoclonal antibody, STRO-1. Blood 1991; 78(1):55-62.

21. Bensidhoum M, Chapel A, Francois S, Demarquay C, Mazurier C, Fouillard L, et al. Homing of in vitro expanded Stro1- or Stro-1+ human mesenchymal stem cells into the NOD/ SCID mouse and their role in supporting human CD34 cell engraftment. Blood 2004; 103(9):3313-9.

22. Dennis JE, Carbillet JP, Caplan AI, Charbot P. The STRO1+ marrow cell population is multipotential. Cells Tissues Organs 2002; 170(2):73-82.

23. Povsic TJ, Zavodni KL, Kelly FL, Zhu S, Goldschmidt-Clermont PJ, Dong C, et al. Circulating progenitor cells can be reliably identified on the basis of aldehyde dehydrogenase activity. J Am Coll Cardiol 2007; 50(23):2243-8.

24. Pearce DJ, Taussing D, Simpson C, Allen K, Rohatiner AZ, Lister TA, et al. Characterization of cells with a high aldehyde dehydrogenase activity from cord blood and acute myeloid leukemia samples. Stem Cells 2005; 23(6):752-60.

\section{Correspondence address:}

Cíntia de Vasconcellos Machado

Rua Marechal Floriano, 354/204

40110-010 Salvador, Bahia, Brasil

Fone: 7181671709 / 41038645

E-mail: cintiamachado@hotmail.com

Recebido: 19/01/15. Aceito: 10/09/15. 